\title{
FAKTOR YANG MEMPENGARUHI PEMBERIAN MAKANAN PENDAMPING ASI TERHADAP BERAT BADAN ANAK USIA 6-24 BULAN DI PUSKESMAS CLUWAK KABUPATEN PATI
}

\author{
Catur Saptaning Wilujeng ${ }^{\star 凶}$, Yuseva Sariati ${ }^{\star \star}$, Ranthy Pratiwi ${ }^{* \star}$
}

\begin{abstract}
Abstrak
Berat badan merupakan ukuran antropometri yang dipakai sebagai indikator yang terbaik untuk mengetahui keadaan gizi dan tumbuh kembang anak. Salah satu faktor yang paling mempengaruhi berat badan adalah pemberian Makanan Pendamping Air Susu Ibu (MP ASI). Data pemberian MP ASI pada anak usia 6-23 bulan di Puskesmas Cluwak Kabupaten Pati Jawa Tengah tahun 2015 masih sangat rendah yaitu sebesar 23,33\%. Penelitian ini bertujuan untuk mengetahui hubungan faktor yang mempengaruhi pemberian Makanan Pendamping Air Susu Ibu (MP ASI) terhadap berat badan anak usia 6-24 bulan di Puskesmas Cluwak Kabupaten Pati Jawa Tengah. Penelitian ini menggunakan metode observasional analitik dengan pendekatan cross sectional. Metode sampling yang digunakan adalah purposive sampling, dengan jumlah sampel 91 anak. Analisis data penelitian menggunakan uji Chi-Square dan regresi logistik. Hasil penelitian menunjukkan bahwa terdapat hubungan antara faktor yang mempengaruhi pemberian Makanan Pendamping Air Susu Ibu (MP ASI) yaitu faktor usia pertama ( $p=$ $0,000)$, jenis $(p=0,000)$, frekuensi ( $p$ value $=0,000$ dan jumlah $(p=0,002)$ pemberian MP ASI terhadap berat badan anak umur 6-24 bulan di Puskesmas Cluwak Kabupaten Pati Jawa Tengah. Hasil analisis regersi logistik menunjukkan bahwa faktor yang paling mempengaruhi berat badan anak umur 6-24 bulan adalah jenis dan usia pemberian MP ASI.
\end{abstract}

Kata Kunci: berat badan anak, MP ASI

\section{FACTORS AFFECTING OF COMPLEMENTARY FEEDING PRACTICES ON 6-24 MONTHS CHILDREN'S WEIGHT IN CLUWAK COMMUNITY HEALTH CENTER IN PATI DISTRICT}

\begin{abstract}
Body weight is anthro-pometric measure to determine the nutritional status and child development. One of the most affecting factor of body weight is complementary feeding practices. Data from Cluwak community health center about complementary feeding practices on 6-24 months children are still very low, amounting to $23.33 \%$. The aim of this research was to know the correlation between factors affecting of complementary feeding practices on 6-24 months children's weight in Cluwak community health center, district of Pati in central java. This research was used survey analytic observational method with cross sectional approach. The sampling method used was purposive sampling, with a sample size was 91 respondents. Analysis of the research was using Chi-Square and logistic regression. The results showed that there was a significant correlation between factors affecting of complementary feeding practices consist of age of children ( $p$ value $=0,000)$, variety ( $p$ value $=0,000)$, frequency $(p$ value $=0,000$ ) and quantity $(p$ value $=0,002$ ) on $6-24$ months children's weight in Cluwak community health center, district of pati in central java. The logistic regression analysis showed the most significant factors affecting of complementary feeding practices on children's weight was a variety of complementary feeding and the first age of giving complementary food.
\end{abstract}

Keywords: children's weight, complementary feeding

* Program Studi IImu Gizi, FK UB
** Program Studi S1 Kebidanan, FK UB

$\square_{E}$-mail:catursaptaning@gmail.com 


\section{Pendahuluan}

Kebutuhan dasar pangan merupakan salah satu kebutuhan dasar yang utama untuk keperluan kesehatan dan pertumbuhan serta perkembangan bayi dan balita. ${ }^{1} \mathrm{ASI}$ memenuhi seluruh kebutuhan energi dan zat gizi lainnya bagi bayi sampai usia 6 bulan untuk tumbuh sehat dan kuat serta mengandung zat antiinfeksi yang melindungi bayi dan anak dari diare dan infeksi lainnya. Sampai usia 6 bulan, kebutuhan energi bayi masih dapat dipenuhi dari ASI. Mulai usia 6 bulan kebutuhan energi bayi tidak dapat dipenuhi dari ASI saja sehingga perlu tambahan energi dari makanan pendamping ASI (MP ASI). ${ }^{2}$ MP ASI, baik tekstur, frekuensi dan porsi makan harus disesuaikan dengan tahap perkembangan dan pertumbuhan anak usia 6-24 bulan. Siregar (2004) menjelaskan bahwa pertumbuhan dan perkembangan bayi dan balita sebagian besar dipengaruhi oleh jumlah ASI dan MP ASI. ${ }^{3}$

Keadaan gizi merupakan gambaran dari apa yang dikonsumsi oleh seseorang dalam jangka waktu yang cukup lama. Karena itu, ketersediaan zat gizi di dalam tubuh seseorang termasuk bayi dan balita akan menentukan keadaan gizi bayi dan balita. Pemberian makanan yang berkualitas dan kuantitasnya baik akan menunjang tumbuh kembang, sehingga bayi dapat tumbuh normal dan sehat serta terbebas dari penyakit. Makanan yang diberikan kepada bayi dan balita digunakan untuk pertumbuhan badannya yang bisa dilihat dari keadaan berat badan bayi. ${ }^{1}$

Berat badan merupakan ukuran antropometri yang terpenting dan harus diukur saat pemeriksaan bayi dan balita pada semua kelompok umur. Berat badan merupakan hasil peningkatan atau penurunan semua jaringan yang ada pada tubuh, antara lain tulang, otot, lemak, cairan tubuh dan lain-lain. Pada saat ini, berat badan dipakai sebagai indikator yang terbaik untuk mengetahui keadaan gizi dan tumbuh kembang anak karena berat badan sensitif terhadap perubahan ${ }^{4}$
Menurut Bappenas tahun 2012, secara nasional, prevalensi berat-kurang pada balita tahun 2013 adalah $19,6 \%$ terdiri dari $5,7 \%$ gizi buruk dan $13,9 \%$ gizi kurang. Jika dibandingkan dengan angka prevalensi nasional tahun 2007 (18,4\%) dan tahun 2010 $(17,9 \%)$ terlihat meningkat. ${ }^{5}$ Dinas kesehatan Propinsi Jawa Tengah (2012), menjabarkan bahwa di Kabupaten Pati, bahwa pemberian MP ASI pada usia 6-23 bulan pada keluarga miskin masih sangat rendah. Dari 6.644 jumlah total balita yang terdiri dari 3.270 laki-laki dan 3.374 perempuan, hanya 550 balita saja yang mendapatkan MP ASI, dengan kata lain masih terdapat $5094(76,67 \%)$ bayi dan balita yang masih belum mendapatkan MP ASI. ${ }^{6}$

Dinas Kesehatan Propinsi Jawa Tengah (2012), menjabarkan bahwa pendataan gizi buruk di Jawa tengah didasarkan pada dua kategori yaitu membandingkan berat badan dengan umur $(\mathrm{BB} / \mathrm{U})$ dan berat badan dengan tinggi badan (BB/TB). Deteksi dini pertama dilakukan di posyandu dengan membandingkan berat badan dengan umur melalui kegiatan penimbangan; jika ditemukan balita yang berada di bawah garis merah (BGM) atau dua kali tidak naik (2T) maka dilakukan konfirmasi status gizi dengan menggunakan indikator berat badan menurut tinggi badan. ${ }^{6}$

Berdasarkan uraian di atas, maka ingin diketahui faktor yang mempengaruhi pemberian makanan pendamping ASI (MP ASI) terhadap berat badan anak usia 6-24 bulan di Puskesmas Cluwak, Kabupaten Pati.

\section{Bahan dan Metode}

Desain penelitian adalah observasional analitik dengan pendekatan cross sectional. Teknik sampling yang digunakan adalah purposive sampling. Dalam penelitian ini digunakan sampel sebanyak 91 anak usia 6-24 bulan di Puskesmas Cluwak, Kabupaten Pati, Jawa Tengah. Pengukuran variabel independen (faktor-faktor yang mempengaruhi pemberian MP ASI) adalah menggunakan usia pertama, jenis, frekuensi dan jumlah pemberian 
menggunakan kuisioner yang telah diuji validitas dan reliabilitas dengan nilai Croncbach alpha sebesar 0,812. Pengukuran variabel dependen (berat badan anak) menggunakan timbangan bayi dan timbangan injak. Teknik analisis data menggunakan uji statistik $\mathrm{Chi}$ Square dengan derajat kepercayaan 95\% dengan $a=0,05$ dan untuk mengetahui faktor pemberian MP ASI yang paling mempengaruhi berat badan anak digunakan uji regresi logistik.
Hasil

Hasil penelitian pada Tabel 1 menunjukkan dari 91 responden, lebih dari setengah responden mendapatkan MP ASI pada usia $>6$ bulan dengan persentase sebesar $58,2 \%$ (63 responden), frekuensi pemberian 34 kali per hari dengan persentase sebesar 46,1\% (42 responden), jenis MP ASI yaitu makanan keluarga dengan persentase sebesar $41,7 \%$ (38 responden) dan jumlah pemberian $3 / 4$ gelas nasi ditambah satu potong lauk dengan persentase sebesar $43,9 \%$ (40 responden).

Tabel 1. Faktor yang mempengaruhi pemberian makanan pedamping air susu ibu (MP ASI)

\begin{tabular}{lcc}
\hline $\begin{array}{l}\text { Faktor yang Mempengaruhi } \\
\text { pemberian MP ASI }\end{array}$ & Jumlah & $\%$ \\
\hline Usia Pertama & & \\
$\quad$ < 6 bulan & 28 & 30,8 \\
> 6 bulan & 63 & 58,2 \\
Total & 91 & 100 \\
\hline Frekuensi & & \\
2-3 kali/hari & 27 & 29,7 \\
3-4 kali/hari & 42 & 46,1 \\
> 4 kali/hari & 22 & 24,2 \\
Total & 91 & 100 \\
\hline Jenis Makanan & & \\
Lumat & 16 & 17,6 \\
lembik & 37 & 40,7 \\
Keluarga & 38 & 41,7 \\
Total & 91 & 100 \\
\hline Jumlah & & \\
2-3 sdm & 17 & 18,7 \\
1/2-3/4 gelas & 34 & 37,4 \\
3/4 gelas + 1 potong lauk & 40 & 43,9 \\
& 91 & 100 \\
\hline
\end{tabular}

Data distribusi berat badan anak usia 6-24 bulan dari hasil penelitian pada Tabel 2 menunjukkan 91 responden dengan lebih dari setengah responden memiliki berat badan normal dengan prosentase sebesar 56\% (51 responden).

Tabel 2. Distribusi berat badan anak usia 6-24 bulan

\begin{tabular}{lcc}
\hline Berat Anak & Jumlah & $\%$ \\
\hline Tidak Normal & & \\
$\quad$ Kurang & & \\
Sangat kurang & 16 & 17,6 \\
Lebih & 2 & 2,2 \\
& 22 & 24,2 \\
Normal & 51 & 56,0 \\
Total & 91 & 100 \\
\hline
\end{tabular}


Analisis Hubungan Faktor yang Mempengaruhi Pemberian MP ASI terhadap Berat Badan Anak Usia 6-24 Bulan:

Hasil analisis data pada Tabel 3 dapat diketahui bahwa dari 91 responden, sebanyak 63 responden yang memberikan MP ASI pada usia yang benar memiliki berat badan normal dengan prosentase 50,5\% (46 responden). Sebanyak 46 responden yang memberikan jenis MP ASI yang benar memiliki berat badan normal dengan persentase 44,0\% (40 responden). Sebanyak 45 responden yang memberikan frekuensi MP ASI yang benar memiliki berat badan normal dengan persentase 38,5\% (35 responden). Sebanyak 53 responden yang memberikan jumlah MP ASI yang benar memiliki berat badan normal dengan persentase $40,7 \%$ (37 responden).

Hasil uji statistik untuk variabel usia pertama pemberian MP ASI dengan $a=0,05$ diperoleh nilai $p=0,000$ maka hasil uji statistik dikatakan signifikan sehingga terdapat hubungan antara usia pertama pemberian MP ASI dengan berat badan anak usia 6-24 bulan. Pada variabel jenis MP ASI yang diberikan, diperoleh nilai $p=0,000$ maka hasil uji statistik dikatakan signifikan sehingga terdapat pengaruh antara jenis pemberian MP ASI terhadap berat badan anak usia 6-24 bulan. Pada variabel frekuensi pemberian MP ASI diperoleh nilai $p=0,000$, maka hasil uji statistik dikatakan signifikan sehingga terdapat hubungan antara frekuensi pemberian MP ASI dengan berat badan anak usia 6-24 bulan dan untuk variabel jumlah diperoleh nilai $p=0,002$ maka hasil uji statistik dikatakan signifikan sehingga terdapat hubungan antara jumlah pemberian MP ASI dengan berat badan anak usia 6-24 bulan.

Tabel 3. Analisis hubungan antara faktor-faktor yang mempengaruhi pemberian MP ASI terhadap berat badan anak usia 6-24 Bulan

\begin{tabular}{|c|c|c|c|c|c|c|c|c|c|}
\hline & \multirow{3}{*}{ Variabel } & & \multicolumn{4}{|c|}{ Berat Badan } & \multicolumn{2}{|c|}{ Total } & \multirow{3}{*}{$p$} \\
\hline & & & \multicolumn{2}{|c|}{ Normal } & \multicolumn{2}{|c|}{ Tidak Normal } & \multirow{2}{*}{$\Sigma$} & \multirow{2}{*}{$\%$} & \\
\hline & & & $\mathrm{n}$ & $\%$ & $\mathrm{~N}$ & $\%$ & & & \\
\hline \multirow{2}{*}{1.} & & Salah & 5 & 5,5 & 23 & 25,3 & 28 & 30,8 & \multirow{2}{*}{0,000} \\
\hline & Usia & Benar & 46 & 50,5 & 17 & 18,7 & 63 & 69,2 & \\
\hline \multirow[b]{2}{*}{2.} & & Salah & 11 & 12,1 & 34 & 37,4 & 45 & 49,5 & \multirow{2}{*}{0,000} \\
\hline & Jenis & Benar & 40 & 44,0 & 6 & 6,6 & 46 & 50,5 & \\
\hline \multirow{2}{*}{3.} & Frolunnci & Salah & 16 & 17,6 & 30 & 33,0 & 46 & 50,5 & \multirow{2}{*}{0,000} \\
\hline & riekuenisl & Benar & 35 & 38,5 & 10 & 11,0 & 45 & 49,5 & \\
\hline \multirow{2}{*}{4.} & & Salah & 14 & 15,4 & 24 & 26,4 & 38 & 41,8 & \multirow{2}{*}{0,002} \\
\hline & Jumlant & Benar & 37 & 40,7 & 16 & 17,6 & 53 & 58,2 & \\
\hline
\end{tabular}

Analisis Faktor yang Paling Berpengaruh terhadap Berat Badan Anak Usia 6-24 bulan:

Hasil analisis data secara regresi logistik pada Tabel 4 menunjukkan bahwa faktor yang paling mempengaruhi berat badan anak usia 6-24 bulan pada anak adalah jenis pemberian MP ASI $(p=0.000)$ dan usia awal pemberian MP ASI $(p=0.004)$.

Tabel 4 . Analisis multivariat regresi logistik

\begin{tabular}{lcccc}
\hline \multirow{2}{*}{ Variabel } & \multirow{2}{*}{$\mathrm{N}$} & OR & \multicolumn{2}{c}{$\mathrm{Cl}(95 \%)$} \\
\cline { 4 - 5 } & & & Lower & Upper \\
\hline Usia & 0.004 & 6.811 & 1.872 & 24.776 \\
Jenis & 0.000 & 13.935 & 4.376 & 44.375 \\
\hline
\end{tabular}




\section{Pembahasan}

Hubungan Usia Awal Pemberian MP ASI dengan Berat Badan:

Hasil analisis hubungan usia awal pemberian MP ASI dengan berat badan anak usia $6-24$ bulan didapatkan nilai $p=$ $0,000(p<0,05)$ (lihat Tabel 3). Hasil analisis menunjukkan bahwa usia awal pemberian MP ASI memiliki hubungan terhadap berat badan anak usia 6-24 bulan di Puskesmas Cluwak Kabupaten Pati Jawa Tengah.

Pada bayi usia 6-23 bulan, selain ASI bayi mulai bisa diberi makanan pendamping ASI, karena pada usia tersebut bayi sudah mempunyai refleks mengunyah dengan pencernaan yang lebih kuat. ${ }^{7}$ Pemberian MP ASI yang kurang tepat digolongkan pada pemberian MP ASI pada umur $<6$ bulan dan pemberian MP ASI yang tepat digolongkan pada anak yang diberikan MP ASI pada umur $\geq 6$ bulan. ${ }^{8}$

Ibu-ibu di daerah pedesaan cenderung memberikan MP ASI pada usia kurang dari 6 bulan akan tetapi tidak sedikit pula dari para ibu yang sudah mulai memberikan MP ASI setelah 6 bulan. Pemberian MP ASI dini di daerah pedesaan biasanya lebih banyak disebabkan oleh alasan budaya dan kepercayaan masyarakat setempat. Hal ini berkaitan dengan masih kuatnya pengaruh dukun kampung dan orang tua yang masih berpegang pada adat kebiasaan lama secara turun temurun dan masih dipatuhi oleh ibu-ibu muda.

Menurut Notoadmojo (2003) ada banyak faktor yang menyebabkan ibu memberikan MP ASI dini pada bayi diantaranya yaitu pengetahuan, informasi yang diperoleh seorang ibu terkadang sangat minim karena pengetahuan yang tidak dimilikinya. Masih rendahnya pengetahuan ibu tentang pemberian MP ASI dipengaruhi oleh banyak faktor yaitu umur ibu, pendidikan, pekerjaan dan sosial ekonomi. Keterkaitan usia ibu dengan usia awal pemberian MP ASI dapat yaitu bahwa peningkatan usia ibu dapat mempengaruhi pengalaman ibu dalam mengasuh anak dan pengetahuan ibu lebih banyak mengenai MP ASI. ${ }^{9}$ Penelitian terdahulu juga menunjukkan bahwa terdapat hubungan antara pola pemberian nutrisi pada bayi yang salah satunya adalah usia pertama pemberian dengan status gizi berdasar berat badan menurut usia,yang menunjukkan adanya perbedaan pertumbuhan antara anak yang tidak mendapatkan MP ASI dan yang telah mendapatkan MP ASI. ${ }^{10}$

Hubungan Jenis Pemberian MP ASI dengan Berat Badan:

Hasil analisis hubungan jenis pemberian MP ASI dengan berat badan anak usia 6-24 bulan didapatkan nilai $p=$ $0,000(p<0,05)$ (lihatTabel 3$)$. Hasil analisis menunjukkan bahwa jenis MP ASI memiliki hubungan terhadap berat badan anak usia 6-24 bulan di Puskesmas Cluwak Kabupaten Pati Jawa Tengah.

Pengenalan dan pemberian MP ASI harus dilakukan secara bertahap baik bentuk maupun jumlahnya, sesuai dengan kemampuan pencernaan bayi/anak. Proses ini juga membutuhkan keterampilan motorik oral. Keterampilan motorik oral berkembang dari refleks menghisap menjadi menelan makanan yang berbentuk bukan cairan dengan memindahkan makanan dari lidah bagian depan ke lidah bagian belakang. ${ }^{11}$ Sebagai panduan pemberian MP ASI, Organisasi Kesehatan Dunia (WHO) mensyaratkan saat yang tepat pemberian makanan pada bayi merupakan upaya pengenalan bertahap, mulai dari makanan murni cair (ASI), makanan lunak (bubur susu), kemudian makanan lembek (tim saring), makanan agak kasar, hingga makanan padat (makanan orang dewasa) pada usia diatas 12 bulan. ${ }^{12}$

Faktor yang mempengaruhi jenis pemberian MP ASI yaitu umur ibu, pendidikan, pekerjaan dan sosial ekonomi. ${ }^{7}$ Berdasarkan hasil penelitian didapatkan 
tingkat pendidikan terakhir ibu adalah SMA sebanyak 52 orang $(57,1 \%)$, SMP 33 orang $(36,3 \%)$ dan masih ada 6 orang $(6,6 \%)$ ibu dengan pendidikan terakhir SD serta tidak ada ibu dengan pendidikan terakhir perguruan tinggi.

Hubungan Frekuensi Pemberian MP ASI dengan Berat Badan:

Hasil analisis hubungan frekuensi pemberian MP ASI dengan berat badan anak usia 6-24 bulan didapatkan nilai $p=$ $0,000(P<0,05)$ (lihatTabel 3). Hasil analisis menunjukkan bahwa frekuensi pemberian MP ASI memiliki hubungan terhadap berat badan anak usia 6-24 bulan di Puskesmas Cluwak Kabupaten Pati Jawa Tengah.

Pemberian makanan pendamping ASI baik tekstur, frekuensi dan porsi makanan harus disesuaikan dengan tahap perkembangan dan pertumbuhan bayi dan anak usia 6-24 bulan. ${ }^{2}$ Frekuensi pemberian makanan pendamping ASI berdasarkan pada usia anak adalah anak usia 6-8 bulan diberikan MP ASI berupa makanan lumat sebanyak 2-3 kali sehari dengan penambahan makanan selingan 1-2 kali sehari, anak usia 9-11 bulan diberikan makanan lembik sebanyak 3-4 kali sehari dengan makanan selingan 1-2 kali sehari, serta anak usia 12-24 bulan diberikan makanan keluarga sebanyak 3-4 kali sehari dengan pemberian makanan selingan 2 kali sehari. $^{2}$

Hubungan Jumlah Pemberian MP ASI dengan Berat Badan:

Hasil analisis hubungan jumlah pemberian MP ASI dengan berat badan anak usia $6-24$ bulan didapatkan nilai $p=$ $0,002(p<0,05)$ (lihatTabel 3$)$. Hasil analisis menunjukkan bahwa jumlah pemberian MP ASI memiliki hubungan terhadap berat badan anak usia 6-24 bulan di Puskesmas Cluwak Kabupaten Pati Jawa Tengah.

Makanan pendamping ASI baik tekstur, frekuensi dan porsi makan harus disesuaikan dengan tahap perkembangan dan pertumbuhan bayi dan anak usia 6-24 bulan. Kebutuhan energi dari makanan adalah sekitar 200 kkal per hari untuk bayi usia 6-8 bulan, 300 kkal per hari untuk bayi usia 9-11 bulan dan 550 kkal per hari untuk anak usia $12-23$ bulan. ${ }^{13}$

Penelitian di Kabupaten Kendal yang menyatakan bahwa ada hubungan antara tingkat konsumsi makanan dengan status gizi bayi umur 6-12 bulan. ${ }^{14}$ Hasil penelitian ini juga didukung oleh hasil penelitian yang menyatakan bahwa tingkat kesehatan gizi sesuai dengan konsumsi pangan, tingkat kesehatan gizi terbaik adalah kesehatan gizi optimum dimana keadaan kesehatan gizi tergantung dari tingkat konsumsi. Jadi, dapat disimpulkan bahwa tingkat kesehatan ditentukan dengan asupan gizi yang masuk ke dalam tubuh. Jika jumlah asupan makanan yang masuk ke dalam tubuh kurang tepat dapat memicu terjadinya gizi kurang, jika jumlah asupan makanan yang masuk ke dalam tubuh berlebih akan memicu terjadinya gizi lebih. ${ }^{15}$

Kejadian masih rendahnya pengetahuan ibu tentang pemberian MP ASI dipengaruhi oleh banyak faktor yaitu umur ibu, pendidikan, pekerjaan dan sosial ekonomi. ${ }^{9}$

Faktor yang Mempengaruhi Berat Badan Anak Usia 6-24 Bulan:

Hasil analisis pada Tabel 3 menunjukkan bahwa ada hubungan usia awal, jenis, frekuensi dan jumlah pemberian MP ASI terhadap berat badan anak usia 624 bulan. Untuk mengetahui faktor mana yang paling berpengaruh terhadap berat badan anak usia 6-24 bulan, maka dilakukan uji regresi logistik. Dari hasil uji regresi logistik (lihatTabel 4) diketahui bahwa faktor yang paling berpengaruh terhadap berat badan anak usia 6-24 bulan adalah usia awal dan jenis pemberian MP ASI. Anak usia 6-24 bulan yang mendapatkan jenis pemberian MP ASI yang salah akan 
mengalami berat badan tidak normal dengan kemungkinan risiko terjadinya adalah 13,9 kali daripada anak yang pemberian MP ASInya sesuai dengan jenisnya, dan anak yang mendapatkan pemberian MP ASI pada usia yang salah atau tidak sesuai usianya akan mengalami berat badan tidak normal dengan kemungkinan risiko terjadinyaadalah 6,8 kali daripada anak yang pemberian MP ASI-nya sesuai usianya.

Usia pertama dan jenis MP ASI yang diberikan merupakan faktor utama yang paling bermakna hubungannya terhadap berat badan anak usia 6-24 bulan. Akibat yang ditimbulkan karena pemberian MP ASI tidak sesuai umur meliputi jangka panjang dan jangka pendek. Akibat jangka pendek yang ditimbulkan adalah infeksi saluran pencernaan dan kekurangan gizi. Sedangkan akibat jangka panjang yang timbul adalah obesitas karena asupan energi yang berlebih karena lambung yang sudah terbiasa mendapat asupan energi berlebih akan terasa kurang apabila yang dimakan hanya sekedar mencukupi kebutuhan harian. ${ }^{16}$

Frekuensi dan jumlah pemberian MP ASI bisa dipengaruhi oleh jumlah makanan atau minuman yang masuk (intake) dan keluar (out-take) pada tubuh seorang anak serta aktifitas anak terhadap frekuensi dan jumlah pemberian MP ASI yang berhubungan dengan metabolisme anak. Selain itu masalah status gizi yang salah satunya berat badan berdasarkan usia, merupakan masalah multifaktorial yang tidak hanya disebabkan oleh pola pemberian MP ASI yang salah. Masalah gizi pada umumnya disebabkan oleh kemiskinan, kurangnya ketersediaan pangan, sanitasi lingkungan yang buruk, kurangnya pengetahuan masyarakat tentang gizi, menu seimbang dan kesehatan. ${ }^{17}$

\section{Kesimpulan}

Kesimpulan dari penelitian ini adalah bahwa faktor yang paling berpengaruh terhadap berat badan anak usia 6-24 bulan adalah usia awal dan jenis pemberian MP ASI. Anak usia 6-24 bulan yang mendapatkan jenis pemberian MP ASI yang salah akan mengalami berat badan tidak normal dengan kemungkinan risiko terjadinya adalah 13,9 kali daripada anak yang pemberian MP ASI-nya sesuai dengan jenisnya, dan anak yang mendapatkan pemberian MP ASI pada usia yang salah atau tidak sesuai usianya akan mengalami berat badan tidak normal dengan kemungkinan risiko terjadinyaadalah 6.8 kali daripada anak yang pemberian MP ASI-nya sesuai usianya.

\section{Saran}

Pada penelitiannya selanjutnya diharapkan dapat meneliti status gizi berdasarkan indikator lain seperti berat badan berdasarkan tinggi badan serta perlu meninjau aspek lain yang dapat mempengaruhi pemberian MP ASI terhadap berat badan seperti kondisi sosial atau kondisi sakit pada anak.

\section{Daftar Pustaka}

1. Maryunani A. Ilmu Kesehatan Anak dalam Kebidanan. Jakarta: Trans Info Media. 2010.

2. Perinasia. Manajemen Makanan Pendamping Air Susu Ibu (MP ASI). Jakarta: PERINASIA. 2014.

3. Siregar. Pemberian Air Susu Ibu (ASI) Ekslusif dan Faktor-faktor yang Mempengaruhinya. Sumatera Utara: Universitas Sumatera Utara. 2004.

4. Soetjiningsih\& Ranuh IGNG. Tumbuh Kembang Anak. Jakarta: EGC. 2012.

5. Badan Penelitian dan Pengembangan Kesehatan Kementerian Kesehatan RI. 
Riset Kesehatan Dasar. Jakarta: Badan Penelitian dan Pengembangan Kesehatan Kementerian Kesehatan RI. 2013.

6. Kementerian Kesehatan Republik Indonesia. Profil Kesehatan Provinsi Jawa Tengah Tahun 2012. Jakarta: Kementerian Kesehatan Republik Indonesia. 2014.

7. Gibson RS, Ferguson EL \& Lehrfeld J. Complementary Foods for Infant Feeding in Developing Countries: Their Nutrient Adequacy and Improvement. I Clinical Nutrition. 2008; 72:421-429.

8. Bogue J. Parental Perceptions of Feeding Practices in Five European Countries: An Exploratory Study. J Clinical Nutrition. 2007; 61:946-956.

9. Notoatmodjo. Pendidikan dan Perilaku Kesehatan. Jakarta: Rineka Cipta. 2003.

10. Hidayat. Hubungan antara Pola Pemberian Nutrisi Saat Bayi Berusia 0-6 Bulan dengan Status Gizi Balita di Wilayah Kerja Puskesmas Kenjeran Surabaya. Jurnal Gizi Pangan. 2009.

11. Sulistidjani. Menjaga Kesehatan Bayi dan Balita. Jakarta: Puspa Swara. 2004.

12. World Health Organization. Infant and Young Child Feeding. Switzerland:WHO Press. 2009. p 3-19.

13. Bowman BA and Russel RM. Present Knowledge in Nutrition. $8^{\text {th }}$ Edition. Washington DC: ILSI Press. 2001.

14. Larasati W. Hubungan antara Praktik Pemberian Makanan Pendamping ASI (MP ASI) dan Penyakit Infeksi Kaitannya dengan Status Gizi pada Bayi Umur 6-12 bulan. Tugas Akhir. Tidak Diterbitkan. Semarang: Universitas Negeri Semarang. 2010.

15. Sediaoetama AJ. IImu Gizi Untuk Mahasiswa dan Profesi. Jilid II. Jakarta: Dian Rakyat. 2000.

16. Departemen Kesehatan Republik Indonesia. Pedoman Umum Gizi Seimbang. Jakarta: Departemen Kesehatan. 2007.
17. Almatseir S. Prinsip Dasar IImu Gizi. Jakarta: Gramedia Pustaka Utama. 2004. 